\title{
The Significance of Super Depo Sutorejo: Waste Management Project in Surabaya Municipality, Indonesia
}

\author{
Yohanes Kambaru Windi ${ }^{1,2 *}$, Dyah Wijayanti ${ }^{1}$, Eko Rustamaji Wiyatno ${ }^{1}$, Loetfia D Rahariyani ${ }^{1}$
}

\author{
${ }^{1}$ Department of Nursing, Politeknik Kesehatan Kementerian Kesehatan Surabaya, Surabaya, Indonesia \\ 2Department of Epidemiology and Preventive Medicine, Faculty Medicine, Nursing and Health Science, School of Public Health and Preventive, \\ Monash University, Australia
}

\begin{abstract}
The Super Depo Sutorejo Surabaya (SDSS) project was created to separate household waste into fractions, but its separation effect is unknown. This study assessed the significance of the project in sorting general waste into biodegradable, non-biodegradable, and assorted. The t-test compared the means of general and biodegradable waste (normally distributed). The non-biodegradable and assorted waste were not significantly distributed; therefore, the Wilcoxon Signed Ranks Test was used to compare their medians against general waste. The multivariate analysis compared the significance level of each waste fraction. Each statistical analysis showed that the SDSS significantly sorts the general waste. The $p$-values were $(0.000)<0.05$ for each type of waste fraction. Furthermore, the multivariate analysis showed that all variables were similar, and $p$-values $(0.00)<0.05$. The biodegradable waste was the most significant fraction (Mean = 176,715.9; SD = 57,990.8), followed by the assorted (Mean = 171,412.5; SD =94,631.3), and non-biodegradable (Mean = 35,243.8; SD = $17,290.7)$. The results showed that the SDSS significantly segregates general waste into biodegradable, non-biodegradable, and assorted, therefore hypothesis $(\mathrm{H} 1)$ is accepted. This study recommends the Government of Surabaya to maintain and expand this waste management project throughout the city alongside the improvement of the community participation program.
\end{abstract}

Keywords: assorted waste, biodegradable, non-biodegradable, sorting, waste

\section{Introduction}

Cities located in both developed and developing countries worldwide are confronted with devastating waste generation.1,2 The Department of Ecology, State of Washington reported that city waste reached 9.7 million tons a year. ${ }^{3}$ Melbourne City produced 10 million tons of garbage in $2016 .{ }^{4}$ Furthermore, Kuala Lumpur, Malaysia, produced 3,000 tons of waste per day. ${ }^{5}$ The Capital of Indonesia, Jakarta, generated 6,500 tons of waste each day, and Surabaya generated 1,450-2,000 tons per day. ${ }^{6-8}$

Waste handling requires adequate resources, advanced technology, and innovation. However, funding shortages, limited waste collection coverage, lack of knowledge on handling waste, coupled with irresponsible behaviors and practices of the residents in treating household waste pose challenges to city authorities. ${ }^{9}$ The World Bank stated that waste management is expensive and may take up $50 \%$ of the budget of cities. ${ }^{10}$

The Government of Surabaya (GoS) has made substantial achievements in waste management. This made the city to have one of the best practices in waste man-

Correspondence*: Yohanes Kambaru Windi, Department of Nursing, Politeknik Kesehatan Kementerian Kesehatan Surabaya, Pucang Jajar Tengah Street No. 56, Surabaya, Indonesia, Email: windi.yohanes@poltekkesdepkes-sby.ac.id, Phone: +628113475137 agement in Indonesia. ${ }^{11-13}$ Various environment-friendly programs have been implemented, such as communitybased composting, use of waste bank (residents deposit their recyclable waste for money). Other practices include spreading net between river banks to catch trashes and riverbank cleaning competition for residents living along the bank to maintain the rivers cleanliness. Currently, the GoS has introduced the "bus waste" in which passengers use plastic mineral water bottles as their tickets. The city also introduced the Black Soldier Flies (BSF) using the black flies' larvae to consume the biodegradable waste. ${ }^{14-16}$

Regardless of the tireless efforts of the GoS in caring for the waste of the city, the waste generation of residents is still alarming. Currently, it is obvious that the aforementioned waste handling practices have not entirely resolved waste matters. In 2015, waste production ranged between 1,450-2,000 tons per day. 7,13 The amount of waste generated in 2018 was 1,600 tons daily. ${ }^{17}$ Waste began to pose a serious problem when adequate waste management was unavailable. The situation was worsened when households as the main generator of waste

Received : March 03, 2020

Accepted : February 05, 2021

Published: May 28, 2021 
failed to treat waste properly at home. Studies in different areas of Indonesia showed that community participation and poor awareness of residents to segregate garbage at the household level are still low. ${ }^{18-20}$

Responding to this issue, the GoS introduced advanced waste management, known as Super Depo Sutorejo Surabaya (SDSS) project. This is a collaborative project between the city of Surabaya and its sister city, Kitakyushu, Japan. The Nishihara Cooperation in Japan provides supervision, managerial, and technical supports for SDSS management. The project is aimed to separate the household general waste into three fractions; recyclable (non-biodegradable), organic (biodegradable), and assorted (miscellaneous) wastes. The management used biodegradable waste as raw materials for composting, sold non-biodegradable waste to recycling companies, and disposed of the miscellaneous or assorted waste to landfills.

Furthermore, the GoS claimed that the SDSS project is one of the city's best practices on waste management. ${ }^{21,22}$ The project has been operating for nearly seven years since 2013. Based on the authors' point of view, the significance of the project in sorting waste before dumps from unusable fractions into landfills is unknown. This study aimed to assess the significance of the SDSS project in sorting general waste into biodegradable, nonbiodegradable, and unusable-assorted waste. It was hypothesized (H1) that the SDSS project significantly sorted general waste into biodegradable, non-biodegradable, and assorted waste. Furthermore, this study was essential to assess the significance of the SDSS project as a sustainable waste management for the city of Surabaya.

\section{Method}

This study took place in the SDSS warehouse at Dukuh Village, Mulyorejo Subdistrict, Surabaya, East Java Province, Indonesia. It occupies nearly 1,483 $\mathrm{m}^{2}$ alongside Kali Waron Street surrounded by crowded housing. A small river, called Kali Waron, flows just a few meters in front of the depo. The SDSS site is used as a temporary waste dumpsite for households before the dump trucks collect and disposed of the rubbish into the landfills. Additionally, the project sorted the general waste of two villages (Dukuh and Kalisari) comprising a total of 8,564 households. The waste collectors (known as Tukang Sampah in the Indonesian term) collect the general waste from door to door and drop the garbage at the SDSS warehouse, while residents pay them for these services.

This is a quantitative study using statistical tools for data analysis, comparing the means between the general waste and the means of the three fractions of waste sorted (biodegradable, non-biodegradable, assorted waste). The SDSS has a well-documented data of the general waste processed and the three waste fractions starting from January 2014 to December 2018. The record shows that the total weight of the general waste $(4,599,256$ $\mathrm{kgs})$, biodegradable $(2,120,519 \mathrm{kgs})$, non-biodegradable $(422,926 \mathrm{kgs})$, and assorted waste $(2,056,944 \mathrm{kgs})$. The waste records from 2014 to 2018 were all taken as the samples of the study. Data collection began with scrutinizing the weight $(\mathrm{kgs})$ records of general waste processed from January 2014 to December 2018. The total number of each general, biodegradable, nonbiodegradable, and assorted waste were recorded in a spreadsheet file. Afterwards, the authors calculated the total monthly waste of each group. The data were then simplified into the annually based calculation (see Table $1)$.

Data were statistically analyzed and followed the three steps. Firstly, the analysis began with the testing of data normality using the Kolmogorov-Smirnov test. This test showed that the biodegradable waste fell into a normal distribution, $p$-value $(0.191)>0.05$. Meanwhile, the distribution of the non-biodegradable waste was identified $(p$-value $=0.01)<0.05$, and the remaining waste debris $(p$-value $=0.00)<0.05$ were not normally distributed. Secondly, the paired t-test was used to compare the means of general and biodegradable waste. Since both non-biodegradable and assorted waste were not normally distributed, the Non-Parametric Wilcoxon Signed Ranks test was performed to compare the medians of the general waste against non-biodegradable and assorted waste. Thirdly, multivariate analysis was also used to identify the most significant fractions of waste sorted from the waste processed.

\section{Results}

The SDSS is a warehouse which contains two waste conveyor belts, a waste-washing machine, a grinding or crusher machine, and a packing machine. A small office is available for three staff of Dinas Kebersihan dan Pertamanan Kota Surabaya (DKPK), the department responsible for waste management and city park maintenance. The management installed a digital scale at the entrance floor to measure the weight of waste before and after the sorting process, and these records constituted the data set for this study.

The SDSS management employed 25 people to sort the waste. They were previously self-employed waste pickers at this temporary dumpsite, while some were itinerant waste pickers. The workers were bound to a oneyear formal contract, which was extendable. The management paid USD 66.32 a month to the waste sorters, including a top-up incentive, approximately USD 22.1129.48 per month, from the money earned, from selling non-biodegradable waste. Therefore, the workers took home payments of about USD 88-99.8 a month. 
Table 1. The Weight of Waste Loaded and Processed at The Super Depo Suterejo Surabaya Warehouse (2014-2018) (kgs)

\begin{tabular}{lccccccc}
\hline Year & Waste Processed & Biodegradable & $\%$ & Non-Biodegradable & $\%$ & Assorted Waste & $\%$ \\
\hline 2014 & $3,161,853$ & $1,355,028$ & 42.9 & 238,930 & 7.6 & $1,567,814$ & 49.6 \\
2015 & $3,037,107$ & $1,638,707$ & 53.9 & 238,601 & 7.9 & $1,159,908$ & 38.2 \\
2016 & $3,842,899$ & $2,237,927$ & 58.2 & 362,158 & 9.4 & $1,248,812$ & 32.5 \\
2017 & $5,684,276$ & $2,574,094$ & 45.3 & 625,974 & 11 & $2,484,204$ & 43.7 \\
2018 & $7,270,145$ & $2,797,198$ & 38.5 & 68,965 & 8.9 & $3,823,982$ & 52.6 \\
\hline \multirow{2}{*}{ Average } & $4,599,256$ & $2,120,519$ & 47.8 & 422,926 & 8.9 & $2,056,944$ & 43.3 \\
\hline
\end{tabular}

Table 2. Results of t-test on Paired Sample of Processed and Biodegradable Waste

\begin{tabular}{|c|c|c|c|c|c|c|c|}
\hline & \multicolumn{4}{|c|}{ Paired Difference } & \multirow{3}{*}{$\mathrm{t}$} & \multirow{3}{*}{ df } & \multirow{3}{*}{ Sig. (2-tailed) } \\
\hline & \multirow{2}{*}{ Mean } & \multirow{2}{*}{ SD } & \multicolumn{2}{|c|}{ 95\% CI } & & & \\
\hline & & & Lower & Upper & & & \\
\hline Waste processed - Biodegradable waste & $206,555.433$ & $108,511.205$ & $178,524.017$ & $234,586.850$ & 14,745 & 59 & .000 \\
\hline
\end{tabular}

Notes: $\mathrm{SD}$ = Standard Deviation; $\mathrm{CI}$ = Confidence Interval; $\mathrm{df}=$ Degree of Freedom

Table 3. Results of Wilcoxon Signed Ranks Test

\begin{tabular}{lccc}
\hline & $\mathbf{N}$ & $\mathbf{Z}$ & Asymp. Sig. (2-tailed) \\
\hline $\begin{array}{l}\text { Non-biodegradable waste - Waste processed } \\
\text { Assorted waste - Waste processed }\end{array}$ & 60 & $-6,736^{\mathrm{b}}$ & .000 \\
\hline
\end{tabular}

The working process begins when some of the Tukang Sampah rummages from door to door, collect, and transport waste to the SDSS warehouse. The carts pass the weighing scale to record the amount of trash before waste collectors load the rubbish onto the conveyor. The conveyor belt then moves forward, and the waste sorters (standing along with the conveyor belts) start separating the non-biodegradable (recyclable waste) and biodegradable waste (e.g., food leftovers, leaves, etc. from general waste) and place them into containers. Some workers also load the sorted non-biodegradable waste into the washing machine and leave for a couple of days to dry up. Finally, the workers pack and stack the nonbiodegradable waste waiting for the recycling company for collection.

Similarly, some waste sorters work on biodegradable waste. They contain the biodegradable waste into several baskets, loaded into a grinding machine to produce waste debris for composting purposes. Other workers scale the waste fraction and wait for the trucks to collect and transport them to the composting warehouse about $5 \mathrm{~km}$ away. Meanwhile, workers receive the unusable miscellaneous waste at the end-point of the conveyor, load into carts, scale them at the entrance, and stack them in the front yard. The available trucks then transport the waste remains to the landfills.

The SDSS capacity is $500 \mathrm{~kg} /$ hour and treats nearly
Table 4. Descriptive Analysis of Multivariate Test

\begin{tabular}{lrrl}
\hline & Mean & SD & N \\
\hline Biodegradable & $176,715.90$ & $57,990.79$ & 60 \\
Non-biodegradable & $35,243.80$ & $17,290.68$ & 60 \\
Assorted waste & $171,412.52$ & $9,4631.32$ & 60 \\
\hline
\end{tabular}

Note: $\mathrm{SD}=$ Standard Deviation

approximately 10 tons of garbage in one day. However, the records showed that the SDSS project operates beyond its capacity. The households' general waste generation is also on the increase. Table 1 describes the accumulation and outputs of waste sorting at SDSS. The record of waste handled by the SDSS was approximately $3,161,853 \mathrm{kgs}$ in 2014 , gradually increased to $3,842,899$ $\mathrm{kgs}$ in 2016 and reached 7,270,145 kgs in 2018. Biodegradable waste was the highest fraction $(47.8 \%)$, followed by miscellaneous $(43.3 \%)$ and non-biodegradable waste $(8.9 \%)$. Therefore, the SDSS project reduced waste sent to the landfill for final disposal by $56.7 \%$. The non-biodegradable waste only reached $8.9 \%$ for the recycling process.

Table 2 shows the results of the t-test statistical analysis. The paired t-test of processed and biodegradable waste produced the $p$-value $(0.000)<0.05$. This signified that the SDSS project significantly segregated biodegradable waste from general.

Similarly, the Wilcoxon signed-rank test showed that 
Table 5. Multivariate Test

\begin{tabular}{llcccccc}
\hline Effect & & Value & F & Hypothesis df & Error df & Sig. & Partial Eta Square \\
\hline Intercept & Pillai's Trace & .284 & $7.391^{\mathrm{b}}$ & 3.000 & 56.000 & .000 & .284 \\
& Wilks' Lambada & .716 & $7.391^{\mathrm{b}}$ & 3.000 & 56.000 & .000 & .284 \\
& Hotelling's Trace & .396 & $7.391^{\mathrm{b}}$ & 3.000 & 56.000 & .000 & .284 \\
& Roy Largets Root & .396 & $7.391^{\mathrm{b}}$ & 3.000 & 56.000 & .000 & .284 \\
\hline
\end{tabular}

Note: $\mathrm{df}=$ Degree of Freedom

the medians of both non-biodegradable and miscellaneous waste were considerably lower after processing at the SDSS warehouse, p-values $(0.00)<0.05$. Both paired t-test and Wilcoxon Signed-Rank tests confirmed that the SDSS project significantly separated general waste into non-biodegradable and assorted waste (Table 3 ).

To identify the most significant among the three outputs of waste processing, the descriptive analysis of the multivariate test showed that the biodegradable waste (Mean $=176,715.9$; SD $=57,990.8)$ was the most significant fraction, followed by the assorted (Mean = 171,412.5; SD = 94,631.3), and non-biodegradable $($ Mean $=35,243.8 ; \mathrm{SD}=17,290.7)$ (Table 4). Therefore, the SDSS sorts more biodegradable waste compared to the other waste fractions.

Wilks' Lambada analysis was used to measure the simultaneous comparison of variables. It was observed that the value of $F=7.391$ and $p$-value $(0.00)<0.05$. Therefore, the SDSS significantly sorted general waste into three different waste fractions (Table 5).

\section{Discussion}

Sorting waste at the household level is a good waste management practice. It requires a strong commitment of residents to participate in treating their trash before disposal to the landfills. However, studies worldwide showed that community participation in waste segregation was still poor regardless of a continuous campaign. ${ }^{23-26}$ Similarly, this study showed that waste sorting among residents around the SDSS working area was absent, as indicated by the increasing amount of waste sent to the SDSS project for sorting.

The GoS competed with uncontrollable waste generation, low community participation in waste separation, overloading of the landfills, and high cost of waste management. The SDSS project may be a solution to tackle the waste issue of the city. Furthermore, the SDSS project fulfilled the standard of waste management stated in the Act No. 18 of 2008 regarding Waste Management, which requires collection, sorting, and recycling, before final disposal of waste, Reduce, Reuse and Recycle (3Rs) principles of waste management. The 3 Rs principles constitute feasible waste management practiced throughout the world. 9,27,28 These principles were applied by the SDSS project in handling the waste of households in both vil- lages.

The sorting process substantially reduced general waste up to $57.7 \%$, which comprises $47.76 \%$ for biodegradable, and $8.96 \%$ for non-biodegradable waste. Furthermore, only $42.5 \%$ of the household wastes ended up in landfills. This waste handling was a good practice to extend the operation time of the landfills. The city authority of Surabaya will save millions of dollars if this waste treatment operated throughout the city.

The t-test of biodegradable waste concluded that the p-values $(0.00)<0.05$. This showed that the SDSS succeeds in separating biodegradable waste from the general. The Wilcoxon Signed-Rank Test also showed that the pvalues of both non-biodegradable and assorted waste were lower than 0.05, which signified that the SDSS significantly segregates non-biodegradable and assorted waste from general waste. Therefore, the SDSS was a reasonable waste management for the city of Surabaya.

The results of multivariate analysis were similar to the mean comparison above. The multivariate descriptive analysis showed that the waste sorting process at SDSS produced more biodegradable waste (Mean = 176,715.9). This percentage was slightly bigger than the disposed waste $($ Mean $=171,412.5)$. Moreover, biodegradable waste was far bigger than non-biodegradable (Mean $=35,243.8$ ). These results reconfirmed that the percentage of biodegradable waste $(47.8 \%)$ exceeded the other fractions; non-biodegradable $(43.3 \%)$ and disposed waste $(8.9 \%)$. Also, the overall process of waste sorting signified that the SDSS significantly separated the general waste into biodegradable, non-biodegradable, and assorted.

Waste sorting at the point where it is produced, (e.g., households, community, construction, public facilities, industry, etc.) is widely practiced worldwide. ${ }^{29-31}$ For example, waste separation was introduced in Bali, known as the Gianyar Waste Recovery Project, which sorted the waste of over 500,000 households. The sorting process produced biodegradable $(85 \%)$, non-biodegradable $(5 \%)$, and assorted waste fractions. ${ }^{29}$ Furthermore, a study in India showed that waste segregation before final disposal was a workable technology for waste management, as it produced $50 \%$ biodegradable for composting, and $18-20 \%$ reusable or recyclable waste. ${ }^{30}$ Norbu, et $a l .,{ }^{32}$ also observed that the pretreatment of waste for 
composting reduced nearly $40 \%$ of solid waste thrown in landfills. A pilot project in China, at source-separated collection became the priority to overcome household waste. 33

Waste is a disaster for both health and the environment, but it is an economic opportunity for some people (e.g., waste pickers) and recycle businesses. Besides reducing waste sent to, and prolonging the operation of the landfills, the SDSS project provided additional benefits for the city of Surabaya. The project separated nearly $9 \%$ of non-biodegradable waste and earned money from the sales of these recyclable materials. In addition, the recyclable waste generated benefits for both the worker and the SDSS management. Waste sorters potentially earn more incentive when the percentage of re-sellable waste is increased.

Biodegradable waste becomes an investment of the GoS. On average, the SDSS project generated biodegradable waste of 2,121 tonnes/year for raw material of compost. According to the experience of the Gianyar Project, one ton of biodegradable waste produces $300 \mathrm{kgs}$ of compost. ${ }^{32}$ The SDSS project produced 636.3 tonnes $(636,300 \mathrm{kgs})$ compost in a year. Furthermore, the market value of a bag of $40 \mathrm{kgs}$ compost in Surabaya is IDR 30,000 (USD 2.96). 34 The calculation of the economic benefit of the compost is IDR 477,225,00 (USD 47,086) a year. This signifies that compost enables the GoS to save approximately $50 \%$ funding to purchase fertilizers. 35

Waste separation at the source before dumping into landfills are a sustainable and effective strategy to deal with the waste problem. The SDSS project is a success story of waste management in the City of Surabaya. The sorting process reduces nearly $60 \%$ of the waste before transport for final disposal. Waste management practices worldwide showed that waste sorting at the source is a successful mechanism to reduce waste send to landfills, and increase the recycling rate. ${ }^{36}$ For example, the Sweden Waste Management Association reported that source separation reduced waste thrown in landfills from $62 \%$ in 1975 to $1 \%$ in 2016.37

Regardless of the success of SDSS, there are certain drawbacks which require solutions. The project may lessen community participation in waste handling. Although community participation is one of the best waste management practices, improving the awareness of the people is still a major problem in many developing countries. ${ }^{38-40}$ The SDSS could also be contra-productive with a community participation campaign in waste management. Therefore, improving the communitybased waste sorting through the "waste bank" and waste reuse-recycling home industries are essential to maintain household participation and a source of extra income for residents. ${ }^{38-42}$
Millions of waste pickers in developing countries rely on collecting, sorting, and selling recyclable waste. ${ }^{43}$ Waste production, especially recyclable or reused waste, is important for their survival. Therefore, an advanced waste program or technology may be a threat to waste pickers. The integration of waste pickers is practiced worldwide to ensure that the hazardous impacts of waste are properly contained and waste pickers sustain their livelihoods. ${ }^{44-46}$ The policy of the SDSS management to employ waste pickers is a good practice in integrating them into the city waste management. Therefore, the expansion of SDSS in the region of Surabaya also needs to secure the livelihood of waste pickers by involving them within the program.

The success of the SDSS program is not problem-free and bears challenges in the future. The results of this study showed a lacking of community participation and awareness of residents about waste pre-treatment at the household level. A further study is also important to overview the implication of the SDSS project toward these issues. Although the SDSS integrates some waste pickers within the program, further insight is important to overview the implications of the project against the itinerant and waste pickers working in landfills.

\section{Conclusion}

This study concludes that poor awareness of residents to sort waste at the source reflects the consistent increase of waste generation at the household level. The SDSS projects succeeds in separating biodegradable and nonbiodegradable waste from general waste. This results in the reduction of waste for final disposal at landfills. Furthermore, the SDSS is also economically beneficial for the waste sorter as well as the GoS Municipal. These show that the SDSS is a sustainable and reliable waste management for the city of Surabaya. This study, therefore suggests that the GoS expands or duplicates this type of waste management throughout the city and provide a more reliable payment for waste sorters.

\begin{abstract}
Abbreviations
BSF: Black Soldier Flies; GoS: Government of Surabaya; 3Rs: Reduce, Reuse, and Recycle; SDSS: Super Depo Sutorejo Surabaya; CI: Confident Interval; SD: Standard Deviation; df: Degree of Freedom.
\end{abstract}

\section{Ethics Approval and Consent to Participate}

The certificate of Ethical Approval was granted by Monash University Human Research Ethics Committee (MUHREC) No. CF14/23642014001267. The respondents were provided with written informed consent.

\section{Competing Interest}

The author declares that there are no significant competing financial, professional, or personal interests that might have affected the per- 
formance or presentation of the work described in this manuscript.

\section{Availability of Data and Materials}

Research data can be provided upon reasonable request.

\section{Authors' Contribution}

YKW designed the research protocol, developed the research methods and data collection tools, conducted data collection, analyzed the data, and drafted the manuscript. DW developed the research methodology, collected data, and drafted the manuscript. Furthermore, ERW contributed to arranging the research permission, handling data collection tools, collecting, and compiling the data. LDR contributed to developing methods and data collection tools, collecting and analyzing data.

\section{Acknowledgment}

The authors convey their appreciation to Monash University for funding the corresponding author's doctoral degree under the scheme of International Postgraduate Research Scholarship (IPRA) and Australia Postgraduate Award (APA). The author is also grateful to the Director of Poltekkes Kemenkes Surabaya for providing administrative assistance related to research permission. Furthermore, the author also expresses gratitude to the Head and staff of Dinas Kebersihan dan Pertamanan Kota Surabaya, including staff at the SDSS site for providing permission, data, and assistance during data collection.

\section{References}

1. Manus Coffey, Coad A. Collection of municipal solid waste in developing countries. UN-HABITAT; 2010.

2. Hoornweg D, Perinaz Bhada-Tata. What a waste: a global review of solid waste management. Washington: The World Bank; 2015.

3. The Department of Ecology State of Washington reported (DESW). Solid waste and material recovery data; 2016.

4. Balfour C. Waste authority's move to scrap landfills, boost recycling. Herald Sun. Melbourne; 2016.

5. Desa A, Kadir NBA, Yusooff F. Waste education and awareness strategy: towards solid waste management (SWM) program at UKM. Procedia - Social and Behavioral Sciences. 2012; 59: 47-50.

6. Belarminus R. Basuki: Jakarta butuh “Incenerator.” Kompas.com; 2013.

7. Fransilia M. Sampah Surabaya 2.000 ton tiap hari, hanya 500 ton diolah. Surya; 2015.

8. Hakim A. Surabaya siap jadi contoh pengelolaan sampah. Antaranews; 2018.

9. Adrian Coad. Collection of municipal solid waste. UN-HABITAT; 2011.

10. The World Bank. Solid waste management. The World Bank; 2019.

11. Riski P. Surabaya, kota percontohan pengolahan sampah terbaik Indonesia. Mongabay; 2014.

12. Kurnia D. Surabaya dijadikan percontohan pengolahan sampah. Republika; 2018.

13. Hakim A. 2016, Surabaya hasilkan sampah 1.500 ton/hari. www.Metrotvnews.com; 2017.

14. Dhokhikah Y, Trihadiningrum Y. Solid waste management in Asian developing countries: challenges and opportunities. Journal of Applied
Environmental and Biological Sciences. 2012.

15. Effendi Z. Ini solusi Pemkot Surabaya kurangi sampah masuk ke TPA dan pantai. Detiknews; 2017.

16. Pemerintah Kota Surabaya. Pemkot Surabaya kembangkan pengolahan sampah dengan larva; 2018.

17. Marzuki MB. Volume sampah di Surabaya mencapai 1,6 ribu ton perhari. Surabaya Times; 2018.

18. Haswindy S, Yuliana F. Partisipasi masyarakat dalam pengelolaan sampah pemukiman pada Kecamatan Tungkil Ilir Kabupaten Tanjung Jabung Barat. Jurnal Ilmu Lingkungan. 2018; 15 (2): 96.

19. Ahmad F. Partisipasi masyarakat dalam pengelolaan sampah berbasis komunitas lokal. Universitas Indonesia; 2012.

20. Lapik F. Partisipasi masyarakat dalam pengelolaan sampah rumah tangga di Desa Mpanau Kecamatan Sigi Biromaru Kabupaten Sigi. EJournal Geo-Tadulako. 2017.

21. Wiweko S, Hakim A, Leksono AS, Riniwati H. The people-based waste management model in Super Depo Sutorejo Surabaya. International Journal of Humanities, Religion and Social Science. 2018; 2 (6): 2548-5725.

22. Sari N. Metode pengolahan sampah Depo Sutorejo meniru Jepang; 2015.

23. Sheau-Ting L, Sin-Yee T, Weng-Wai C. Preferred attributes of waste separation behaviour: an empirical study. Procedia Engineering. 2016; 145: 738-45.

24. Mukama T, Ndejjo R, Musoke D, Musinguzi G, Halage AA, Carpenter DO, et al. Practices, concerns, and willingness to participate in solid waste management in two urban slums in Central Uganda. Journal of Environmental and Public Health. 2016; 2016.

25. Otitoju TA, Seng L. Municipal solid waste management: household waste segregation in Kuching South City, Sarawak, Malaysia. American Journal of Energy Engineering. 2014; 03 (06): 82-91.

26. Sinthumule N, Mkumbuzi S. Participation in community-based solid waste management in Nkulumane Suburb, Bulawayo, Zimbabwe. Resources. 2019; 8 (1): 30.

27. Sakai SI, Yoshida H, Hirai Y, Asari M, Takigami H, Takahashi S, et al. International comparative study of $3 \mathrm{R}$ and waste management policy developments. Journal of Material Cycles and Waste Management. 2011; 13 (2): 86-102.

28. Samiha B. The importance of the 3R principle of municipal solid waste management for achieving sustainable development. Mediterranean Journal of Social Sciences. 2013; 4 (3): 129-35.

29. Banga M, Banga M. Household knowledge, attitudes and practices in solid waste segregation and recycling: the case of Urban Kampala recycling. Zambia Social Science Journal. 2011; 2 (1).

30. Ajayi SO, Oyedele LO, Akinade OO, Alaka HA. Critical management practices influencing on-site waste minimization in construction projects. Waste Management. 2016; 56: 330-9.

31. Johnson KM, González ML, Dueñas L, Mario G, Relyea G, Luque LE, et al. Improving waste segregation while reducing costs in a tertiarycare hospital in a lower-middle-income country in Central America. Waste Management \& Research. 2013.

32. Zurbrügg C, Gfrerer M, Ashadi H, Brenner W, Küper D. Determinants of sustainability in solid waste management - the Gianyar waste recovery project in Indonesia. Waste Management. 
2012; 32 (11): 2126-33.

33. Jun Tai, Zhanga W, Chea Y, Feng D. Municipal solid waste sourceseparated collection in China: a comparative analysis. Waste Management. 2011; 31 (8): 1673-82.

34. Kushairi. Jual pupuk organik BOKASI; 2017.

35. Hartini D. Sampah disulap jadi pupuk kompos, Pemkot Surabaya hemat anggaran 50 persen!. KompasTV; 2020.

36. Xevgenos D, Papadaskalopoulou C, Panaretou V, Moustakas K, Malamis D. Success stories for recycling of MSWat municipal level: a review. Waste and Biomass Valorization. Springer Netherlands. 2015; 6: 657-84.

37. Rousta K. Household waste sorting at source: a procedure for improvement. University of Boras; 2018.

38. Sinthumle NI, Mkumbuzi SH. Participation in community-based solid waste management in Nkulumane Suburb, Bulawayo, Zimbabwe. Resources. 2019; 8 (1).

39. Yakubu KN, Mado H. Assessment of community participation in solid waste management in Kaduna Metropolis. In: Nigerian Environmental Society National Conference: Deployment of Green Initiatives for Economic Diversification in Africa; 2018.
40. Tanuwijaya F. Partisipasi masyarakat dalam pengelolaan sampah di Bank Sampah Pitoe Jambangan Kota Surabaya. Universitas Airlangga Surabaya; 2016.

41. Sudati Nur Sarfiah WJ. Manfaat bank sampah bagi masyarakat di Dusun Semali Desa Salamkanci Kecamatan Bandongan Kabupaten Magelang. Jurnal REP (Riset Ekonomi Pembangunan). 2017; 2 (2): 165-84.

42. Hakim A. Puluhan warga Surabaya peroleh manfaat kelola bank sampah. Antara Jatim; 2018.

43. Women in Informal Employment: Globalizing and Organizing (WIEGO). Waste pickers. WIEGO; 2012.

44. Chikarmane P. Integrating waste pickers into municipal solid waste management in Pune, India. WIEGO Policy Br (Urban Policies); 2012.

45. Masood M, Barlow CY. Framework for integration of informal waste management sector with the formal sector in Pakistan. Waste Management \& Research. 2013; 31 (10 SUPPL.): 93-105.

46. Sembiring E, Nitivattananon V. Sustainable solid waste management toward an inclusive society: integration of the informal sector. Resources, Conservation \& Recycling. 2010; 54 (11): 802-9. 